[Running heads: verso KATHERINE SHINGLER

recto BLAISE CENDRARS'S DAN YACK]

\title{
AN ART NOVEL FOR THE AGE OF MECHANICAL REPRODUCTION: BLAISE CENDRARS'S DAN YACK
}

\author{
KATHERINE SHINGLER \\ UNIVERSITY OF NOTTINGHAM
}

\section{Abstract}

This article considers Blaise Cendrars's novel Dan Yack (1929) as a variation on the art novel genre, arguing that it rewrites and adapts well-worn art narratives - most notably various iterations of the Pygmalion myth - in order to question the nature and function of art in the age of mechanical reproduction. The first part of the novel investigates traditional art forms, especially sculpture, and describes the failure of the sculptor Sabakoff to attain the Pygmalionesque dream of divine creative power. The second part apparently advances the mechanical art forms of sound recording and cinema as alternative modes of representation more responsive to modern experience; but these too are seen to fail to breathe life into the work of art, producing no more than a sterile imitation of reality and, in the case of cinema, endlessly rehashing past narratives. This pessimism about art is also brought out through the novel's intertexts, which insist on the dangers and limits of artistic creation. Drawing on Walter Benjamin, the article suggests that this pessimism may be tempered somewhat (though certainly not eliminated), since Cendrars's text itself provides a model of an art that works to make the impoverished experience of modern life meaningful by relating it to tradition.

Blaise Cendrars's Dan Yack, published in two parts in 1929 and reissued as a single volume in 1946, is certainly not a conventional novel: it lacks consistent, linear plot development and narrative continuity, and its peripatetic structure and shifts in narrative perspective give rise to a somewhat disjointed, fragmented text. Nor is Dan Yack an art novel in a very conventional sense: in contrast to the best-known nineteenth-century examples of the genre, such as Balzac's Le Chef-d'œuvre inconnu, Zola's L'Euvre, or the Goncourts' Manette Salomon, Cendrars's protagonist is not an 
artist, and the novel does not present itself explicitly as a vehicle for the discussion of aesthetic theory. ${ }^{1}$ Nevertheless, while Dan Yack may be read as a story about modern man's quest for identity, inseparable from that quest is an engagement with the nature and function of art, or with the question of how to express oneself in the early twentieth century, which Walter Benjamin characterized as the age of mechanical reproduction. Close examination of the novel also reveals a wealth of embedded references to a tradition of stories about artistic creation, stretching from Ovid to Poe and beyond, which provide points of departure for Cendrars's enquiry. This article will consider the ways in which the author appropriates and adapts these stories in his representations of sculpture and the new technologies of cinema and sound recording, and will show that in doing so, Cendrars queries the status of the latter as privileged instruments of expression for the modern age.

From his collaborations with Sonia Delaunay (on the 1913 'livre simultané' La Prose du Transsibérien) and Fernand Léger (on the 1919 illustrated book La Fin $d u$ monde filmée par l'ange N.-D.) to his Dix-neuf poèmes élastiques, Cendrars's early works display a recurrent concern with the visual arts and their relationship to writing. In the post-war period, however, a series of articles published in La Rose rouge reveal a steady disillusionment with painting, and with cubism in particular, which Cendrars found to be fatally constrained by its own rules and drained of life by its limited palette. ${ }^{2}$ This series culminated in the 1926 article 'Pour prendre congé des peintres',

\footnotetext{
${ }^{1}$ For an overview of the genre see Paul Smith, 'Literature and Art', in The NineteenthCentury Art Novel, ed. by P. Smith (= special issue of French Studies, 61 (2007)), pp. $1-13$.

${ }^{2}$ See especially 'Quelle sera la nouvelle peinture?', in Blaise Cendrars, Tout autour d'aujourd'hui, ed. by Claude Leroy, 15 vols (Paris: Denoël, 2001-06), XI, 53-54, and
} 
in which Cendrars bluntly stated that 'les peintres modernes m'ont profondément décu', blaming the art market for corrupting aesthetic values and arguing, by way of a lengthy quotation from Kipling's Letters of Travel ('Half a dozen pictures'), that artistic representations are a poor substitute for the experience of life itself, and that both artists and consumers of art would do better to get out and see the world than to ignore it in favour of a few dabs of paint within a frame. ${ }^{3}$ This notion of the estrangement of art from life forms one of the cornerstones of Cendrars's art-critical stance in Dan Yack. Indeed, much later in his career, in his 1950s radio interviews with Michel Manoll, Cendrars stated in relation to the novel that 'les artistes vivent à côté, en marge de la vie et de l'humanité', and added that he did not consider himself to be an artist. $^{4}$

Dan Yack is also resolutely not an artist: he even prides himself on never having read a book. In the first part of the novel, Le Plan de l'aiguille, this rich heir to a shipping conglomerate is jilted by his lover and, in a bid to find himself, to establish himself anew, sets off from St Petersburg to the Antarctic. He takes with him on his journey three artists, against whom he is defined: André Lamont, a composer, Arkadie Goischman, a poet, and Ivan Sabakoff, a sculptor. ${ }^{5}$ They resolve to stay on a remote, 'Pourquoi le “cube” s'effrite?', XI, 57-60. This edition of Cendrars's collected works will hereafter be abbreviated to ' $T A D A$ ', and references will cite volume and page numbers only, not individual volume titles.

${ }^{3}$ Blaise Cendrars, 'Pour prendre congé des peintres', in TADA, XI, 81-86 (p. 81).

${ }^{4}$ Blaise Cendrars vous parle..., in TADA, XV, p. 26.

${ }^{5}$ These three figures are usually held to be fictional avatars for Stravinksy, Chagall, and Archipenko respectively: see Jay Bochner, Blaise Cendrars: Discovery and Recreation (Toronto: University of Toronto Press, 1978), p. 170; and Pascaline Mourier- 
uninhabited island for a year, and the action centres on the inevitable self-destruction of the artists, whose creative resources are too weak or too ill-adapted to be able to survive the tough conditions, and whose demise speaks volumes of the state of the arts as Cendrars sees it. Lamont proves to be unable to live or to create without his 'auditoire habituel' made up of fawning women. ${ }^{6}$ In the moment where he realizes that his symphony is 'ratée', he can think of nothing better than to cry for his lover — who, moreover, kills him by infecting him with syphilis. While Lamont, therefore, represents artistic decadence and the dangerous, emasculating influence of women over the male artist, the poet Goischman is seen to be motivated entirely by money ('Il faut bien vivre' (p. 20)), but the irony is that his work has earned him 'pas un radis' (p. 20). Creatively and sexually impotent, when his scurvy-ridden body begins to disintegrate, he finally cuts off his nose, in a pathetic parody of Van Gogh, his creative achievement amounting to no more than a 'plagiat [...] raté' (p. 94). In Goischman, Cendrars provides a portrait of the artist who pursues art for all the wrong reasons not only for money, but also because he is seduced by the myths surrounding avantgarde creation, of which Van Gogh was so emblematic in this period. ${ }^{7}$ Goischman's symbolic castration and concomitant impotence bespeak the vacuity and failure that such myths serve to conceal.

Casile, 'L'Eil de Cendrars', Revue des sciences humaines, 216 (1989), 111-32 (pp. $120-21)$.

${ }^{6}$ Blaise Cendrars, Dan Yack, in TADA, IV, 46. Page numbers for subsequent references to the novel are given in parentheses in the text.

${ }^{7}$ See Nathalie Heinich, La Gloire de Van Gogh: essai d'anthropologie de l'admiration (Paris: Éditions de Minuit, 1991), esp. pp. 207-22. 
Sabakoff, the sculptor, is a rather more complex and appealing figure. While his companions are motivated by baser concerns, he declares, 'Moi, moi, je travaille pour l'Art' (p. 18). He is not impotent or weak, and he busies himself with practical tasks on the island, while his fellow artists wither away. Unlike Lamont and Goischman, who immediately become alienated from the vigorous and practical Dan Yack, Sabakoff forms a close friendship with the latter; the material nature of his medium also contrasts with the abstract, immaterial non-creation of the other artists, resurrecting the hope of an art that remains grounded in the stuff of life itself. And yet Sabakoff also dies, crushed by his own statue of Dan Yack. The question, of course, is why, and what this death signifies within the novel's art-critical schema.

Cendrars's choice of sculpture as representative of the visual arts may move us some way towards an answer to this question. This choice, as Claude Leroy has noted, may be motivated partly by the fact that Cendrars had already explicitly 'taken leave' of painting: 'À quoi bon la congédier une seconde fois?" ${ }^{8}$ But the representation of sculpture in narrative fiction also inevitably raises the spectre of Pygmalion, the sculptor who, in Ovid's tale, brought his sculpture to life. Sabakoff is closely linked to this myth of the artist, in a lengthy passage where he dreams of a sculpture representing a primordial creation myth, and in which the artist himself is figured as a divine forger giving life to humanity. At the summit of this colossal monument is a single figure:

Il se levait. Il faisait le tour du dernier pic de la montagne et s'élevait graduellement. Marche par marche, il montait de face, de trois quarts, de dos. Toujours plus haut,

\footnotetext{
${ }^{8}$ Claude Leroy, 'L'Atelier du double: Cendrars et Léger en miroir', in Dis-moi, Blaise: Léger, Chagall, Picasso et Blaise Cendrars [exhibition catalogue] (Paris: Réunion des musées nationaux, 2009), pp. 15-23 (p. 19).
} 
toujours plus haut. Enfin, il se détachait seul sur le vide. Il avait atteint le sommet. Une boule, une sphère, un globe, la terre, une lampe, le soleil, qu'il tentait d'arracher, de soulever et de maintenir, haut, très haut en l'air, à bout de bras, sans faiblir. Prométhée! (p. 54)

The monument culminates, then, in a representation of the artist's own heroic effort of creation, and as he, like Prometheus, seizes divine power, his sculpture becomes animated - it is alive with movement. ${ }^{9}$ The conflation of the myths of Prometheus and Pygmalion in this passage is one that, as Anne Geisler-Smzulewicz has demonstrated, was extremely common in nineteenth-century versions of the Pygmalion story: whereas in Ovid's tale the sculpted figure came to life through the intervention of Venus (and the sculptor himself, while skilled, remained a mere mortal), modern retellings attributed Galatea's animation to the artist's own quasi-divine creative powers. ${ }^{10}$ Pygmalion thus took on the heroic, rebellious quality of Prometheus, who

\footnotetext{
${ }^{9}$ That Cendrars conceives Sabakoff's sculpture as animated is also confirmed in his 1936 text Hollywood: la Mecque du cinéma (TADA, III, 1-137), where he states that a cinematic song-and-dance number is 'une page arrachée à mon roman Le Plan de l'aiguille', and cites this particular passage (pp. 96-97). The attainment of movement in sculpture is also a key concern in other texts, such as 'Dialogue sur la sculpture', in Blaise Cendrars, Inédits secrets, ed. by Miriam Cendrars (Paris: Club français du livre, 1969), pp. 388-94, and the poem 'La Tête', in Dix-neuf poèmes élastiques, in TADA, I, 63-95 (p. 91): 'La sculpture d'Archipenko est le premier œuf ovoïdal | Maintenu en équilibre intense | Comme une toupie immobile | Sur sa pointe animée'.

${ }^{10}$ Anne Geisler-Smzulewicz, Le Mythe de Pygmalion au XIX $X^{e}$ siècle: pour une approche de la coalescence des mythes (Paris: Champion, 1999), p. 73. The conflation between the two myths is also made possible by the fact that Prometheus, in some
} 
had stolen divine powers from the gods. Sabakoff is situated very much within this mythical framework, and within a line of fictional artists whose creative ambitions reach towards the sphere of the ideal and the divine. But, like Prometheus, these artists may be punished for overstepping their bounds, and their creative projects may end in disaster or failure. As such, this intertextual connection raises the suspicion that, like so many other modern Pygmalions — like Frenhofer, like Claude Lantier, who aspire to ideal, life-giving creation yet find that this is out of their reach - Sabakoff cannot but fail to achieve his dream.

As the sun returns to Dan Yack's island after the long polar winter, Sabakoff resolves to make his vision a reality: looking around the stark Antarctic landscape, he resolves to 'peupler tout ça' (p. 79). But his project quickly goes awry. It is not that Sabakoff fails to create — on the contrary, he is incredibly prolific — but rather that the idealism of the project itself leads the sculptor away from the material basis of his art. As Yvette Bozon-Scalzitti puts it, '[1]'idéal de pureté absolue qui anime Ivan mène également à la mort au terme de la dématérialisation parfaite qu'il exige'. ${ }^{11}$ The people over whom Sabakoff reigns as divine creator are increasingly abstract: he creates 'une statue monolithique, une borne humanisée, un glaçon anthropomorphique' (p. 80), and versions of the myth, was a sculptor — variously seen as modelling humans and animals and, in later versions (Goethe and Voltaire), as the creator of Pandora. See Jacqueline Duchemin, Prométhée: histoire du mythe, de ses origines orientales à ses incarnations modernes (Paris: Les Belles Lettres, 2000), pp. 49-50, 119-22; also Emilie Sitzia, L'Artiste entre mythe et réalité dans trois æeuvres de Balzac, Goncourt et Zola (Åbo: Åbo Akademis Förlag, 2004), pp. 29-30.

${ }^{11}$ Yvette Bozon-Scalzitti, Blaise Cendrars; ou, La passion de l'écriture (Lausanne: L'Âge d'homme, 1977), p. 73. 
represents Dan Yack via his monocle, symbolic of his own distorted artistic vision. This movement towards abstraction subsequently veers into the immaterial ('Ivan Sabakoff songeait à une sculpture immatérielle tant son désir de simplification, de purification était grand' (p. 82)), and Prometheus's gift of light becomes a curse as the artist misguidedly seeks to sculpt with it: 'La seule sculpture possible, c'est la lumière. J'y arriverai. Comme un ange' (p. 83). This, clearly, is an artistic ideal taken to an untenable extreme, but Sabakoff's failure also seems inevitable within the conjuncture of the Pygmalion and Prometheus myths: the artist who attempts to transcend the limits of his creative powers must be punished for his hubris. The material accordingly reclaims its rights over the sculptor, and Sabakoff is killed by the statue that would have completed his monument. The latter, as Bozon-Scalzitti notes, is made from a dark 'glace fossile' (p. 92) whose earthy materiality contrasts with his earlier works, sculpted in an ice described as 'fragile, pure, lumineuse, transparente, à peine opaque, presque immatérielle!' (p. 80). ${ }^{12}$ Moreover, as a figurative sculpture of a human form, the statue echoes another legendary narrative about sculpture: the story of the Golem, in Jewish legend an artificial man made of clay, who in some versions rebels against and crushes the creator who dared to bestow on him the divine gift of life. ${ }^{13}$

Even if in the second part of the novel Dan Yack declares that all three artists were 'morts d'impuissance' (p. 250), it must be allowed that Sabakoff's impotence is of a different order to that of his fellow artists. His is not an aesthetic failure Cendrars's aim is not simply to criticize sculptural abstraction — but rather a tragic

${ }^{12}$ Bozon-Scalzitti, Blaise Cendrars, p. 75.

${ }^{13}$ Claude Leroy comments on this connection in his notes on Dan Yack, in TADA, IV, 308 n. 54. Cendrars may have been aware of the Golem legend via Gustav Meyrink's 1915 novel Der Golem, or Paul Wegener's 1920 film adaptation. 
inability to attain an impossible ideal, his struggle made all the more heroic by Cendrars's mobilization of myths of artistic creation. These myths also prepare the way for Dan Yack, the industrialist and the only one of the group to survive the Antarctic sojourn, to assert his own heroic creative power and its superiority over art. For we must not overlook the fact that the statue that kills Sabakoff represents Dan Yack... as Prometheus. Displacing artistic creation with industry, the remainder of Le Plan de l'aiguille deals with Dan Yack's astonishing entrepreneurial achievements, and in particular his rapid construction of a whaling station on the site of 'PortDéception' in the desolate South Shetlands — the name of its antecedent being redolent of the failure of the three artists, while the process of populating the new settlement, the utopian 'Community-City', provides an ironic echo of Sabakoff's thwarted desire to play God, to 'peupler tout ça'. The implication, it seems, is that if art is to continue in any form — and it does, in the form of the novel itself — then Dan Yack's materialist 'art de vivre', and his technologically assisted creative acts, may provide a model where poetry, music, and sculpture have failed.

Alongside industrial forms of creation, an alternative model for art may be provided by new sound technologies, a source of endless fascination to Dan Yack, who declares, 'Je n'aime que le ronron nasillard des phonographes et les cris géants des gramos' (p. 26). These technologies are adopted as an expressive medium by the protagonist in the second part of the novel, Les Confessions de Dan Yack. The 'confessions' narrate, in a jumbled chronological sequence, Dan Yack's return to Europe and participation in the First World War, his marriage to a young girl, Mireille, and her subsequent death; they consist of a number of sound recordings made by Dan 
Yack via dictaphone, which he then sends to a typist to be transcribed. ${ }^{14}$ Crucially, Cendrars also asks the reader to believe that his own creative process was similarly mediated by sound recording, claiming in a foreword that 'Cette Deuxième Partie a été parlée au Dictaphone; elle n'a pas été écrite', and emphasizing that the printed form of the novel is a poor translation of its sonorous essence: 'Quel dommage qu'on n'entende pas la voix de Dan Yack entre ces pages' (p. 161, emphasis original). ${ }^{15}$ Might this new technology, as a mode of representation more responsive to the reality of modern life, be able to replace the sterile and overly idealized forms of art that had been dismissed in Le Plan de l'aiguille?

Clearly, recording technology does not suffer from an excess of idealism: it is attractive to Dan Yack, and to Cendrars, precisely because it is close to life, providing a direct trace of reality. In terms of Cendrars's own work, the concern to record and

\footnotetext{
${ }^{14}$ In the early twentieth century the technology of dictation, performed until the 1950s using wax cylinders, was highly gendered: a male dictator would speak into a recording device, while a female typist listened and transcribed. See David L. Morton, Sound Recording: The Life Story of a Technology (Westport, CT: Greenwood Press, 2004), p. 46. This clearly corresponds with a conception of artistic creation as a masculine endeavour, and of the work as passive, feminine, and formed by the male gaze, which underlies Dan Yack.

${ }^{15}$ The list of locations and dates of composition appended to the end of the novel also includes the claim that it was 'enregistré au Dictaphone quelque part à la campagne: été 1929' (p. 289). On Cendrars's interest in the creative possibilities of sound technology see also Philippe Bonnefis, Dan Yack: Blaise Cendrars phonographe (Paris: Presses universitaires de France, 1992), esp. pp. 8-9.
} 
document experience is in evidence as early as La Prose $d u$ Transsibérien, ${ }^{16}$ and is pursued further in the author's increasing turn to reportage and memoir in his work after Dan Yack. In the novel itself, sound recording is conceived by the protagonist not just as a way to document life but as a way to preserve it, and even to reanimate the past: 'Pour moi,' Dan Yack says, 'le dictaphone est un appareil qui réveille tous les échos' (p. 172). His fascination with the trademark 'la voix de son Maître', associated with the image of the gramophone and 'le petit fox qui lui obéit' (p. 163), reveals that part of the appeal of this technology lies in the illusion of mastery that it affords - the ability to overcome temporal boundaries and to bring back what is irrevocably lost. Dan Yack thus attempts to reanimate his dead wife by reading out and recording her 'cahiers'. But Mireille cannot truly come to life since she is unable to speak for herself: 'la voix de Mireille' is replaced by 'la voix de son Maître', who in reading her words appropriates them and asserts control over her (sonorous) image. Dan Yack's project of reanimation through representation - like Pygmalion's statue, of which this aspect of the novel provides yet another distant echo - is thus seen to be grounded in narcissism rather than love.

But it is not merely because Dan Yack neglected to record Mireille's own voice before her death that his project fails: the recording technology itself is also fragile, meaning that the human voice may be scrambled, distorted, or disrupted. The 'confessions' are frequently fragmentary, and Dan Yack warns his typist that 'ce

${ }^{16}$ See Susan Taylor-Horrex, 'Cendrars, Delaunay, et le simultanéisme: évolution de l'esthétique simultanéiste', in L'Encrier de Cendrars: actes du colloque du centenaire, Berne, Neuchâtel, La Chaux-de-Fonds, Sigriswil, 31 août, $1^{\text {er }}$ et 2 septembre 1987, ed. by Jean-Carlo Flückiger (Boudry-Neuchâtel: La Baconnière, 1989), pp. 209-17 (p. 214). 
rouleau est fêlé. [...] Il est fendu de bout en bout' (p. 171). The needle of the recording apparatus appears as an obsessive motif, which crops up throughout the novel in a variety of substituted forms: in the mountain peaks of the Plan de l'aiguille (an area of the Alps where some of Dan Yack's 'confessions' are recorded), in chimneys, in pine needles even. But the 'Plan de l'aiguille', the ruse of recording, is not without its dangers, since a needle may be harmful as well as salutary. It is frequently associated with death: with the 'trocart' that pierces the whale's flesh (p. 211), with the slaughter of sea lions, whose recorded cries Dan Yack frequently listens to on his gramophone. Observing the mass destruction of human life in the trenches, Dan Yack muses:

Il me semblait qu'une fulgurante épée tombait du haut du ciel et battait des étincelles rugissantes, et sabrait et massacrait tout à la surface du monde comme une aiguille aiguisée de gramophone qui érafle, raie à tort et à travers un vieux disque déjà usé, remonté à fond et dont toutes les voix humaines sont définitivement condamnées. (p. 250)

Like the face that stares out from a faded photograph, the recorded voice is merely a trace of what is dead or irremediably lost to time.

This ambivalence towards sound recording is mirrored in Cendrars's treatment of another technological means of representation in the second half of the novel, where cinema emerges as a further alternative to the obsolete modes of expression dismissed in Le Plan de l'aiguille. Dan Yack puts his wife Mireille in front of the camera, a move that perhaps reflects the author's own involvement in film-making, and his view of cinema as a universal, popular language uniquely appropriate to expressing the modern sensibility. ${ }^{17}$ It is also motivated by an attempt to please Mireille (who in her 'cahiers'

\footnotetext{
${ }^{17}$ See especially 'L'ABC du cinéma', in $T A D A$, XI, 29-33, and also 'Le Principe de l'utilité', in $T A D A$, XI, 35-46 (p. 46). Cendrars collaborated with Abel Gance on
} 
gives a lengthy account of the couple's afternoons spent at rowdy popular cinemas), to make her laugh — metaphorically, to 'animate' her, to bring her to life and to cure her of the mysterious illness that will eventually consume her (and which is characterized by frigidity: like a cold, immovable statue, elle reste de marbre). Dan Yack's ambition, then, is once again to give life through art; but implicit in this ambition is also the desire to create an ideal woman, responsive to his own desires and obedient to 'la voix de son Maitre': the Golem of the first part of the novel thus gives way to Galatea, and the Pygmalion myth raises its head once again. Through cinema Mireille becomes endlessly malleable, pliant to the role she is given. Many of her film roles are multiple, consisting of a combination of different female types that appeal to a range of possible male desires and fantasies: in the film on Edgar Allen Poe she is an amalgam of Eleonora, Ligeia, and Ulalume, while in the Contes d'Hoffmann she is dressed up 'en sylphide, en reine de Saba, en princesse lointaine, en Cendrillon, en fée, en magicienne, en bonne petite servante' (p. 231). ${ }^{18}$ Alongside Mireille's other

J'accuse (1919) and La Roue (1923), although his accounts of his involvement in these films, and of his various other film-making projects, may be somewhat exaggerated: see Blaise Cendrars vous parle..., in TADA, XV, 96, 189. In 1923 he did direct his own film, which survives only via its scénario (La Perle fiévreuse, in Cuvres complètes, 8 vols (Paris: Denoël, 1960-65), IV, 7-61); the film also, apparently, provided the basis for Une nuit dans la forêt. On Cendrars's engagement with cinema in practice and via writing see Mikhail Iampolski, The Memory of Tiresias: Intertextuality and Film, trans. by Harsha Ram (Berkeley: University of California Press, 1998), pp. 125-61; and Francis Vanoye, 'Le Cinéma de Cendrars', Europe, 566 (1976), 183-96.

${ }^{18}$ The mention of the Contes d'Hoffmann brings to mind yet another Galatea: the wax automaton Olimpia who features in the story 'Der Sandmann', and in Offenbach's 
Pygmalion, the director Lefauché, Dan Yack frequently assumes the role of director and producer, coaching her on her gestures and turning her into a film star with mass appeal. Like Galatea, Mireille owes her identity, on and off screen, to her creator, as she confesses in one of her 'cahiers':

Je lui dois tout. Tout ce que je sais, c'est lui qui me l'a appris. Il m'a appris à m'habiller. Il m'a appris à marcher. Il m'a appris à me maquiller. Je dois avouer que, sans lui, je n'aurais jamais su rendre tout ce que j'ai fait dans L'Ève future. (p. 235)

Mireille's role as the artificial woman Hadaly in a film version of Villiers de l'Isle-Adam's L'Ève future is particularly significant in the context of Cendrars's reworking of the Pygmalion myth. Villiers's novel is itself informed by that myth and provides, as Marie Lathers has argued, 'an idealist response to the artist-model plots of realism and naturalism', replacing the real, physiological artist's model with an ideal woman 'modelled' to the desires of her creator. ${ }^{19}$ Like Dan Yack, L'Eve future deals with the question of art in the machine age: both Villiers's Edison and Cendrars's protagonist may be considered as part of a new breed of artist, imagining new forms and profoundly changing human life with their inventions. Dan Yack's project for 'un

opera. On Hoffmann's reworking of the Pygmalion myth see Michelle E. Bloom, 'Pygmalionesque Delusions and Illusions of Movement: Animation from Hoffmann to Truffaut', Comparative Literature, 52.4 (2000), 291-320 (p. 296).

${ }^{19}$ Marie Lathers, Bodies of Art: French Literary Realism and the Artist's Model (Lincoln: University of Nebraska Press, 2001), p. 197. As well as L'Eve future, the figure of the artificial woman may recall Fritz Lang's 1927 film Metropolis, whose ambivalent treatment of the industrial machine also bears resonances with Cendrars's text. 
gramophone géant, dont l'aiguille serait aussi grosse qu'un tire-fond [...], destiné à être dressé sur la place publique de Community-City comme kiosque à musique' (p. 208), would seem to be a conscious echo of Edison as 'papa du phonographe', while the scale of the machine in question recalls some of Edison's more extravagant inventions as presented in $L^{\prime} \dot{E} v e$ future. If these new artists undeniably change human life, however, they do not necessarily change it for the better: the technologies they invent and promote present threats and dangers as well as revitalizing capacities. Nowhere is this more apparent than in the cinematic 'animation' of Mireille: placed in relation to Edison's animation of the 'andréide' Hadaly, whose demise at the end of Villiers's novel appears as a punishment for the inventor's Pygmalionesque attempt to meddle with the divine, this project appears ill-fated from the outset.

For her role as Hadaly, Dan Yack moulds — one might even say sculpts — Mireille into an artificial, mechanical woman, as he has already taught her to correspond to the type of artifical feminine ideal that the cinematic 'machine' (p. 236) demands. She is made up for the camera and coached to move in a deliberately mechanical way: 'Il me réapprenait à marcher, géométriquement, pour le cristallin gradué des objectifs et non plus pour la sensibilité des yeux' (p. 237). Whereas Edison's sculpted android comes to life, this process is almost reversed as Mireille takes on the role of Hadaly, and she complains:

j'ai souffert le martyre durant des mois et des mois, je devais retenir mon souffle, la circulation de mon sang, freiner tous mes sens pour paraître blême, inanimée, sentimentalement amorphe tant que durait la mise au point de la femme artificielle. (p. 233)

Mireille has to become inanimate for this particular role, but more generally her onscreen representation fails to bring her to life, for the cinematic image is only an image 
— and, in the era prior to sound film, a silent image, one that is unable to laugh as Dan Yack so desperately wants it to. As in Dan Yack's dictaphone recordings, Mireille's cinematic representation is unable to speak for itself, or to come to life as anything other than a sterile product of Dan Yack's narcissistic desire. As Dan Yack implicitly recognizes when he tells Mireille 'Tu devrais tourner dans la vie' (p. 235), the cinematic image is artificial — and, like the other art forms explored in the novel, utterly estranged from life.

Rather than giving life, the camera seems to drain it from its subjects. In this respect Cendrars's novel may be seen to look back to certain art narratives of the previous century in which the painted representation is conceived as a parasite and rival to the model, whose life it usurps. In Zola's L'Euvre, for example, Christine senses that posing for Claude's portrait of her means 'prêter sa chair, pour que l'autre naquît'. ${ }^{20}$ Another possible intertext, suggested by Mireille's role as the female lead in a film on Poe, is the latter's The Oval Portrait, where the painted image comes to life but at the cost of the model's death. (Indeed, Cendrars, for the film on Poe, may have had in mind Jean Epstein's 1928 film La Chute de la Maison Usher, which includes key elements from The Oval Portrait. ${ }^{21}$ ) In invoking these nineteenth-century fictional representations of painting, Cendrars's representation of cinema questions whether this

${ }^{20}$ Émile Zola, L'CEuvre, ed. by Marie-Ange Voisin-Fougère (Paris: Librairie générale française, 1996), p. 348.

${ }^{21}$ Francis Vanoye notes this as a possible intertext in his introduction to TADA, III, $\mathrm{p}$. xv. Cendrars's familiarity with Poe was long-standing, as is demonstrated by a 1907 'liste de lecture' that mentions the Nouvelles histoires extraordinaires (in Cendrars, Inédits secrets, p. 28); Villiers and Hoffmann are also mentioned here among Cendrars's early reading matter (pp. 208, 280). 
technologically mediated art form — in the 1920s still regarded as a relatively recent development — could truly be considered to be 'new', or whether it might suffer from the same pathologies that afflict more traditional visual art forms. It simultaneously looks forward, I think, to Walter Benjamin's insistence that the filmic image robs the actor of his aura, his authentic individual presence: Benjamin cites Pirandello, for whom the actor's body 'loses its corporeality, it evaporates, it is deprived of reality, life, voice, and the noises caused by his moving about, in order to be changed into a mute image, flickering an instant on the screen, then vanishing into silence...' ${ }^{22}$

Cendrars's representation of Mireille's cinematic dissection similarly comes as a kind of rewriting of the symbolic violence inflicted on the female model in art narratives of the nineteenth century: L'Euvre, in which Christine is sacrificed to an art that 'la ravalait', once again springs to mind, as perhaps does Edison's lengthy dissection of his 'model' woman, which exposes the intimate physiological/mechanical make-up of Hadaly's body to his guest Lord Ewald's gaze, and to that of the reader. ${ }^{23}$ But it also provides a curious anticipation of Benjamin's analogy between surgeon and cameraman. $^{24}$ The director Lefauché (aptly named, since faucher can mean to kill, to destroy, to cut down, and is suggestive of a Grim Reaper figure) is described by Mireille in the following violent terms:

\footnotetext{
${ }^{22}$ Walter Benjamin, 'The Work of Art in the Age of Mechanical Reproduction', in Illuminations, trans. by Harry Zohn, ed. by Hannah Arendt (London: Pimlico, 1999), pp. $211-44$ (p. 223).

${ }^{23}$ Zola, L'Euvre, p. 344; Villiers de l'Isle-Adam, L'Ève future, ed. by Alan Raitt (Paris: Gallimard, 1993), livre cinquième (pp. 213-69).

${ }^{24}$ Benjamin, 'The Work of Art', pp. 226-27.
} 
Il savait me tirer des larmes, me faire verser de véritables larmes pour ses gros plans.

[...] Ces séances m'exténuaient. Alors il s'acharnait, et quand je n'en pouvais plus, que j'allais m'évanouir, il me retenait encore un instant au tournant de ma défaillance, M. Lefauché, pour faire braquer sur moi un objectif monstrueux, les plus cruels éclairages du studio et fouiller ainsi impitoyablement mon malaise jusqu'au dernier degré de l'exténuation. (p. 234)

One should note that 'un objectif' here can mean a viewfinder for a gun as well as for a camera, while 'braquer' similarly contains the threat of violence as the camera is trained on its subject/victim. Mireille is tortured, the most intimate areas of her self exposed to the gaze of the camera for the benefit of a cinematic art based on scopophilic pleasure. This passage echoes a contemporaneous text by Cendrars, Une nuit dans la forêt, in which the narrator (in this instance identified as Cendrars himself) casts himself as a film director and says of Pompon, his prospective leading lady, 'je l'aurais plantée au bout d'un projecteur comme on épingle un insecte et j'aurais braqué sur elle tous mes objectifs'. ${ }^{25}$ He goes on to describe the instruments of cinematic vivisection:

Le 170 Dallon-Téléphoto qui vous capte un individu et le ligote brusquement comme au lasso, le 120 Dallmeyer qui le dope, le leurre et le transforme en patient, le 100 $B \& L$ Tessar qui l'endort comme au chloroforme et le désanime, le 75 Carl Zeiss Matched qui fend et écartèle les muscles, le 50 Vérito qui griffe et pince les nerfs, le 28 Ultrastigmate qui colore les pensées et le 12 Goerz-Hypar qui compénètre insensiblement votre victime pour se substituer à sa personnalité.

Despite this gruesome description, which equates the camera lens with an instrument of torture, the cinematic 'cut' is conceived as a salutary one: Cendrars insists that his role is like that of the surgeon, talks in the passage just cited about his 'patient' (as well as his 'victime'), and regrets that Pompon refused to be filmed, since 'à elle, cela lui

${ }^{25}$ Cendrars, Une nuit dans la forêt, in TADA, III, 197. 
aurait fait du bien'. ${ }^{26}$ Pompon needs to have the traumatic events of her past quasisurgically exorcized from her psyche. As in Benjamin's analysis, Cendrars believes that the camera's gaze allows the 'optical unconscious', the unseen elements of reality, to be exposed, but this optical unconscious is also analogous to the psychological unconscious. ${ }^{27}$ The camera is thus able to 'fouiller [...] mon malaise', as Mireille puts it. In Dan Yack, as in Une nuit dans la forêt, the incision inflicted by the camera on its subject is intended to reveal, and thereby remove, the psychological trouble that haunts her. Instead, it simply exposes it to her in all its unbearable reality — 'je me voyais révélée à moi-même' (p. 239) — and Mireille dies as a result.

Dan Yack's enthusiastic embrace of the cinema, and of technologies allowing sound to be recorded and replayed, thus gives way to a troubling ambivalence. As arts based on mechanical reproduction, they provoke the same excitement and the same anxiety as all machines in Cendrars's work: potentially generative and productive, they are also registered as a threat, presenting a danger to the human body, and a force that may escape human control. ${ }^{28}$ In Dan Yack this threat is present in the 'détraquement' of the automated 'orchestre de chats', another machine with which the hero is

\footnotetext{
${ }^{26}$ Ibid.
}

${ }^{27}$ Benjamin, 'The Work of Art', p. 230.

${ }^{28}$ See Yvette Bozon-Scalzitti, 'Cendrars et la machine infernale', in Cendrars aujourd'hui: présence d'un romancier, ed. by Michel Décaudin (Paris: Lettres modernes Minard, 1977), pp. 15-33. For a broad analysis of Cendrars's poetic responses to technology and industrialized capitalism see Carrie Noland, 'Blaise Cendrars and the Heterogeneous Discourses of the Lyric Subject', in Poetry at Stake: Lyric Aesthetics and the Challenge of Technology (Princeton, NJ: Princeton University Press, 1999), pp. 89-113. 
fascinated (p. 126); it is present in the violence of the factory equipment at Community-City, which cuts and processes whale carcasses but also rips off the limbs of inattentive workers, and in the monstrous anthropomorphic form of the factory itself, a terrifying melding of human and machine: 'L'usine, la gueule ouverte sur le port, les entrailles à nu, colérique, rageante, avec des explosions brusques de vapeur, des renâclements, le bruit continu de ses formidables mâchoires' (p. 141). But it is most vivid, as we have seen, in Cendrars's exploration of technologically mediated modes of representation, whose products are seen at best to amount to no more than a sterile, artificial imitation of life, and at worst to represent a deadly parasite.

As Dan Yack abandons cinema, and his dictaphone, at the end of Les Confessions, one may detect a certain nostalgia for the traditional arts that were literally and symbolically killed off in Le Plan de l'aiguille: while poetry, music, and sculpture may have been fatally ill-adapted to the realities of life, they are innocuous in comparison to the threat to life presented by mechanical art forms. Related to this, I think, is the fact that Cendrars's text is shot through with intertexuality, constantly glancing back to a rich tradition of narratives about art. ${ }^{29}$ The novel is, in this respect, firmly anchored in the past — a fact that sits awkwardly alongside Dan Yack's insistence that '[i]l faut nous moderniser, c'est de notre âge. Notre génération doit tout recommencer' (p. 122). It is also at odds with Cendrars's own literary image, his

${ }^{29}$ Beyond the art narratives that inform Dan Yack, there may be many other intertexts: the Antarctic expedition in Le Plan de l'aiguille has been linked to Poe's Arthur Gordon Pym (see J.-M. Santraud, 'Dans le sillage de la baleinière d'Arthur Gordon Pym: Le Sphinx des glaces, Dan Yack', Études anglaises, 25.3 (1972), 353-66), and may also be influenced by Jean Charcot's accounts of his expeditions (see TADA, IV, 304 n. 38). 
position at the forefront of the 'Futurist Moment', ${ }^{30}$ a generation of artists and writers whose purpose was to reject passéisme, to renew and reinvigorate artistic forms, to render in their work 'la beauté du monde moderne'. ${ }^{31}$ Claude Leroy has argued that the central dynamic of Dan Yack concerns this imperative to break with the past: the novel is about freeing oneself from the symbolic influence of 'le père', and establishing a new, distinct, 'modern' identity (hence why Dan Yack chooses a new name, rejecting that of his family). Within the framework of this analysis, traditional artistic expression fails because it is unable to detach itself from the past. ${ }^{32}$ In the case of the mechanical

\footnotetext{
${ }^{30}$ Marjorie Perloff, 'Profond Aujourd'hui', in The Futurist Moment: Avant-Garde,
} Avant-Guerre, and the Language of Rupture, 2nd edn (Chicago: University of Chicago Press, 2003), pp. 2-41.

${ }^{31}$ Blaise Cendrars, 'Quels seront les maîtres?' (La Rose Rouge, 1919), in TADA, XI, $55-56$ (p. 56).

${ }^{32}$ Claude Leroy, 'Figures de Dan Yack: le jeu dans l'île', in Cendrars aujourd'hui, ed. by Décaudin, pp. 109-44 (pp. 139-41). According to this analysis, Sabakoff's demise corresponds to his return to an obsolete sculptural tradition, as the sculptor declares shortly before his death, 'J'ai retrouvé la Tradition. J'ai retrouvé la voie de mon père: la Vérité' (p. 81). Rather than relating to a traditional style or mode of representation, however, this statement may actually imply a renewal of mystical or religious artistic traditions, since Sabakoff's father is a sculptor of 'icônes' (p. 21). Following this reading, the artist becomes a sort of mystic, and 'la Vérité' refers to the word that is written on the Golem's forehead by his creator (or inserted into his mouth or chest, in some versions) to bring him to life; see Moshe Idel, Golem: Jewish Magical and Mystical Traditions on the Artificial Anthropoid (Albany, NY: State University of New York Press, 1990), p. 4. 
arts, they fail to come alive because they are constructed so as to reproduce reality rather than to create it; cinema, moreover, is seen simply to rehash literary classics Poe, Hoffmann, Villiers — rather than to forge new narratives. Turning back on itself, meaninglessly repeating, mechanical reproduction can neither resuscitate the past nor breathe new life into the present; as Dan Yack laments, 'Ah! Pourquoi est-ce que tout se répète, puisque rien ne revient?' (p. 267).

Dan Yack certainly does not 'tout recommencer': far from breaking with the past, it recycles and reuses well-worn narrative patterns and inscribes modern experience within tradition. But this does not necessarily imply that it too is a failure. Cendrars's intertextual strategy does not amount to a mechanical repetition or reproduction of other stories, and it stands in contrast to the more direct cut-and-paste technique used to construct Kodak out of Gustave Le Rouge's Le Mystérieux Docteur Cornélius, and to 'Dernière heure', one of the Dix-neuf poèmes élastiques, which was 'copié dans Paris-Midi'. ${ }^{33}$ Cendrars's strategy in Dan Yack consists, rather, in rewriting, or in the adaptation of past narratives to the particular problems of the age of mechanical reproduction. And it may be better understood if we pay attention to Cendrars's own presentation of the novel, in a short text that accompanied the 1929 publication of Le Plan de l'aiguille. ${ }^{34}$ Starting from the premise that 'La modernité a

${ }^{33}$ Cendrars, Dix-neuf poèmes élastiques, in TADA, I, 80. On Kodak's composition see Francis Lacassin, 'Les Poèmes du Docteur Cornélius', in Le Mystérieux Docteur Cornélius et autres æuvres de Gustave Le Rouge, ed. by F. Lacassin (Paris: Laffont, 1986), pp. 1181-1247; and Bozon-Scalzitti, Blaise Cendrars, pp. 297-309, which reveals Maurice Calmeyn's Au Congo belge as another source.

${ }^{34}$ In $T A D A$, IV, 292. This text was later incorporated into Aujourd'hui (1931) under the title 'Le Roman français' (TADA, XI, 49). 
tout remis en question', Cendrars explains that technology has changed not only our surroundings, but the psychological make-up of the human subject — 'sa sensibilité, son émotion, sa façon d'être, de penser, d'agir, tout son langage, bref, la vie'. He goes on:

Cette transformation profonde de l'homme d'aujourd'hui ne peut pas s'accomplir sans un ébranlement général de la conscience et un détraquement intime des sens du cœur: autant de causes, de réactions, de réflexes qui sont le drame, la joie, l'orgeuil, le désespoir, la passion de notre génération écorchée et comme à vif...

Seule la formule du roman permet de développer le caractère actif d'événements et de personnages contemporains qui, en vérité, ne prennent toute leur importance qu'en mouvement.

Depuis quelque cinq ans, le roman français sert dans le monde à la mise au point du nouveau régime de la personnalité humaine. ${ }^{35}$

Cendrars conceives of his novel, then, as a response to modernity and to changes in human consciousness. This may mean attempting to translate the fast-moving nature of modern life into the form of the novel — which the wide-ranging, fragmented narrative of Dan Yack arguably does — but it does not have to mean a naive, Futurist-tinged hymn to modern technology. As the above passage shows, Cendrars is attentive to the shocks and traumas of modern experience; his phrase 'notre génération écorchée et comme à vif' reminds one, once again, of Benjamin, and in particular his exploration of neurasthenia, or mental hypersensitivity, as a modern psychopathology to which Baudelaire had responded in his urban poetry. ${ }^{36}$ And so it may be that part of Cendrars's intention, in his 'mise au point du nouveau régime de la personnalité

\footnotetext{
${ }^{35}$ TADA, IV, 292.

${ }^{36}$ Walter Benjamin, 'On Some Motifs in Baudelaire', in Illuminations, pp. 152-96 (esp. pp. 156-62).
} 
humaine', is not only to describe or explain the modern psyche, but also to treat it mettre au point, in the sense of fixing or fine-tuning a malfunctioning machine. If, according to Benjamin, the modern era's generalized rupture with the past produces an 'increasing atrophy of experience', this must be remedied by reinscribing the present into a continuous narrative that connects it with tradition. That is, relating the present to the past turns the raw experience of the present (Erlebnis) into something meaningful, into 'experience in the strict sense of the word' (Erfahrung) — where individual experiences 'combine with material of the collective past' ${ }^{37}$ Relating Dan Yack's attempts at technologically mediated creation (whether through industrial production, through sound, or through cinema) to tales of pre-technological creation thus parries the shock of the modern and works to inscribe the narrative within a meaningful framework of tradition.

This is, however, about as far as Cendrars's optimism about art goes in Dan Yack. While the text's inscription within literary tradition suggests that art in the modern age may function to give a sense of meaning to an otherwise impoverished experience of the present, its intertexts simultaneously function to indicate the dangers and limits of artistic creation. The Pygmalion myth (in its modern forms, where the possibility of attaining divine creative power is resolutely closed), the legend of the Golem, The Oval Portrait, L'Ève future, and the other narratives about art whose ghosts haunt Dan Yack all tell of the ultimate failure of art to overcome human limits, to change reality, to act as a saviour: in each case, the artist seeks to create life through art, but this culminates in disaster. The anxiety about the power of art that is present in these stories is transposed, in Dan Yack, to the age of mechanical reproduction, where it becomes all the more acute as traditional forms of art seem ill-adapted to the present,

${ }^{37}$ Ibid., pp. 155-56. 
and technologically mediated forms bring new fears to light. The novel circulates around questions concerning the nature of modern art, how it might differ (if at all) from industrial production, and what it can and cannot achieve. As we have seen, Cendrars's novel insists very much on art's limits rather than its possibilities, and even while the text attempts to give some sense of meaning to modern experience, it pessimistically casts doubt on its own ability to achieve this, and leaves many of its own questions about art in the age of mechanical reproduction worryingly unsettled. 